\title{
CREATIVITY AND 'EUREKA' IN SCIENCE AND ENGINEERING
}

\author{
J.L. Steyn ${ }^{1} \&$ A.J . Buys ${ }^{2}$ \\ Graduate School of Technology Management \\ University of Pretoria, South Africa \\ 12asteyn@lantic.net, 2aj.buys@up.ac.za
}

\begin{abstract}
Creativity theory started out on a scientific basis at the beginning of the $20^{\text {th }}$ century; but then the scope broadened and inquiry became more multidisciplinary. In this article it is shown how the current demand for creativity in science and engineering grows faster than the understanding of it. As a result, the broad definition of 'creativity' is refocused on science and engineering by considering its evolutionary roots. Based on an overview of the work of scientists and engineers, a unified theoretical framework for creativity is proposed, and the systemic approach to awareness and creativity is affirmed. This approach - the theoretical framework and the core of current creativity knowledge - is then used to derive a fresh layer of theory that is anchored in the literature and industrial experience.
\end{abstract}

\section{OPSOMMING}

Die teorie van kreatiwiteit het by die aanvang van die vorige eeu op ' $n$ wetenskaplike grondslag begin. Die bestek het toe uitgebrei en mettertyd meer multidissiplinêr geword. In hierdie artikel word getoon hoedat die hedendaagse vraag na die kreatiwiteit van wetenskaplikes en ingenieurs vinniger groei as die begrip daarvan. Die breë kreatiwiteitsdefinisie word, gevolglik, opnuut gefokus op wetenskap en ingenieurswese deur die evolusionêre wortels daarvan te beskou. Gebaseer op ' $n$ oorsigtelike beskrywing van die werk van wetenskaplikes en ingenieurs, word 'n verenigde raamwerk vir kreatiwiteit voorgestel, en die sistemiese benadering tot bewussyn en kreatiwiteit word bevestig. Hierdie benadering - die teoretiese raamwerk en die kern van huidige kennis oor kreatiwiteit - word dan gebruik om 'n vars teoretiese laag af te lei wat in die literatuur sowel as in nywerheidservaring geanker is.

\footnotetext{
${ }^{1}$ The author was enrolled for a PhD in the Graduate School of Technology Management at the University of Pretoria.
} 


\section{INTRODUCTION}

Creativity lies at the core of all invention, innovation, entrepreneurship, and leadership. And at the heart of the creative process, in turn, lies the 'eureka' experience, that precious and joyful event of inspired breakthrough insight (West [47]; Lee [27]; Atkins [2]). Some people reason that not all creative progress happens with dramatic (eureka) breakthroughs. The breakthrough stage is certainly not the same in every case: sometimes the peak is mild and ordinary, while at other times it is sharp and life-changing. This spread results in a range across the creative process, from the everyday to the once-in-a-lifetime experience.

This paper presents the first findings of a research project into the nature and dynamics of creativity and eureka in science and engineering. This first outcome concludes with an incremental layer of fresh theory, but this new theory is already anchored in reality, both in the literature and in industrial experience. The execution of an empirical experiment among scientists and engineers with a creative track record will follow.

\section{THE ROOTS OF TECHNICAL CREATIVITY}

The roots of scientists' and engineers' creativity are found, as with so many other fundamental things, in the human evolutionary past: in the creative struggle for survival and growth (Darwin [8]). In this sense creativity has become the capacity to understand and employ the laws of nature in the struggle for survival and ascendancy. Today one may as well speak of the survival of the most creative as of the fittest.

But the Darwinian creative urge has evolved. As humans evolved from hunter-gatherers to farmers through the first disruptive technological revolution (the agricultural revolution), social structures had to change as people banded together to protect crops and herds against marauders. The agricultural revolution, therefore, introduced not only a new technology, but also a new level of competition and conflict: the clan (Diamond [14]).

Different techno-historians describe the structure of technology revolutions and their attendant societal developments in different ways. The common theme, however, is their wave-like structure and their revolutionary and compressed nature. The evolution of human creativity in response to technology, struggle, competition, and conflict can be seen in Table 1.

\begin{tabular}{|c|c|c|c|}
\hline Period & Revolution & Society & Competition \\
\hline $10 \mathrm{kBC}-10 \mathrm{kCE}$ & Agriculture & Hunter-gatherer & Individuals \\
\hline & & Agrarian & Clans \\
\hline Around 1800 & Industrial & & Nations \\
\hline & & Industrial & Ideologies \\
\hline Around 2000 & Information & & \\
\hline Around 2020 & Biotechnology & Information & Classes? \\
\hline & & Frantic? & \\
\hline
\end{tabular}

Table 1: The evolutionary frame of creativity (Adapted from Wood [48], Davidson [11], and Diamond [14])

Human creativity does not only evolve because of the increasingly complicated nature of technology (the technologies of the various disruptive revolutions are cumulative): it also arises because of the increasingly complicated and intense nature of competition and conflict, whose increase is also cumulative. What is more, the succession of disruptive technological revolutions is compressed: they follow each other with increasing frequency. It is important that creativity should show a correspondingly rapid and exponential increase. 


\section{RAPID DEMAND GROWTH}

Lest the crescendo-like development of technology, illustrated in Table 1, convey the idea that progress is limitless, it must be said that the unfettered growth of the globe's human population has become unsustainable (Sagan [37]). A sustainable society is a one that satisfies its resource requirements without endangering the sustainability of future generations (Capra [7]).

Complex life on planet Earth has become non-sustainable: the extinction rate of life forms increases, non-renewable resources decrease, the natural habitat shrinks, humans no longer live in ecological harmony with their natural environment, the terror threat of weapons of mass destruction increases, the digital divide widens, and ideological radicalism increases. In evolutionary terms, humans have indeed become the earth's ultimate infesting weed.

This is bad news, of course, for humanity. But it is not necessarily bad news for life on Earth. Planet Earth has already experienced at least two mass extinctions (one 245 million years ago, and another 65 million years ago), and life on Earth has recovered from both (Ward [45]). The globe itself is, in fact, quite robust, and really belongs to insects, the maj ority (72\%) of all current life forms (Holm [21]). The last mass extinction was caused by an asteroid impact on the Yucatán, creating extra-ordinary climatic change. Millions of life forms disappeared, including the dinosaurs. Today, signs of a third mass extinction are multiplying, after which life will probably recover and carry on as it has before.

Human life on the planet faces a composite crisis that may take place in the next decade or in the next century. But so far, over the last million years at least, human creativity has ensured the survival and ascendancy of the human species. This time the crisis probably comes neither from space nor from tectonic plates. Rather, it is man-made; and it may very well trigger or accelerate another mass extinction. And this time it is up to humans to prevent or ameliorate and defer it - provided, of course, that human creativity, and hence the capacity for problem-solving, increases at the same rate.

By considering a few high level cumulative changes in industrial management, it is possible to form an idea of the increased current and future challenges for technical leaders, and therefore also of the demands on the creativity of modern scientists and engineers in industry.

\begin{tabular}{|c|c|c|c|c|}
\hline Development in & $\mathbf{1 9 6 0 - 1 9 8 0}$ & $\mathbf{1 9 7 0} \mathbf{- 1 9 9 0}$ & $\mathbf{1 9 8 0 - 2 0 0 0}$ & $\mathbf{1 9 9 0 - \mathbf { 2 0 1 0 }}$ \\
\hline Governance & Shareholders & + Customers & $\begin{array}{c}\text { +All stake- } \\
\text { holders }\end{array}$ & $\begin{array}{c}\text { + Planet's } \\
\text { interests }\end{array}$ \\
\hline Strategy & $\begin{array}{c}\text { LT business } \\
\text { planning }\end{array}$ & $\begin{array}{c}\text { + Corporate } \\
\text { strategy }\end{array}$ & $\begin{array}{c}\text { + Strategic } \\
\text { management }\end{array}$ & $\begin{array}{c}\text { + Strategic } \\
\text { navigation }\end{array}$ \\
\hline Quality & $\begin{array}{c}\text { Quality of } \\
\text { conformance }\end{array}$ & $\begin{array}{c}\text { + Quality of } \\
\text { design }\end{array}$ & $\begin{array}{c}\text { + Total quality } \\
\text { + Sustainable } \\
\text { quality }\end{array}$ \\
\hline Design & Fit for function & $\begin{array}{c}\text { + Design for } \\
\text { manufacture }\end{array}$ & $\begin{array}{c}\text { +Human- } \\
\text { centred design }\end{array}$ & $\begin{array}{c}\text { + Axiomatic } \\
\text { design }\end{array}$ \\
\hline
\end{tabular}

Table 2: Supervisory changes in the technical enterprise over the last half century (Sources include Ansoff [1], Rouse [36] and Suh [44]

The business changes outlined above are mainly the result, in the first place, of the transition from industrial society to information society. But they also align with the industrial response to the threatening global crisis. It is possible, of course, to outline similar changes in the realm of pure science. It would be short-sighted of business and technical leaders to ignore these enduring sea changes. It would be similarly foolish to imagine that human creativity will remain unaffected by their profound consequences for science and engineering. As was pointed out earlier, creativity must increase in adversity. 


\section{A CORRESPONDING SHIFT IN THEORY DEVELOPMENT}

Human creativity has changed over the years. And even over the last century the views of different authors about creativity have undergone significant changes. (For the sake of brevity, only the main citations are referenced.)

At the start of the $20^{\text {th }}$ century, technical people began to concern themselves with the nature of creativity. One of the first (in 1896) was Hermann von Helmholtz, who identified three stages in creative technical work; he was a contemporary of that tireless innovator, Edison. Later came Karl Bühler [6] in 1907 with the isolation of the 'a-hah! moment', and Henri Poincaré [35] in 1908 with his four stage model of creative scientific work. These early insights were integrated in 1926 by Graham Wallas [47], who was also the first to view creativity as a legacy of the evolutionary process.

In about 1900, in his book Psychology of invention in the mathematical field, Jacques Hadamard used introspection to describe mathematical thought processes. He described his own thinking as largely wordless, often accompanied by images that represent the entire solution to a problem. He analysed the work of many of his peers, and found this same "viewing of entire solutions with sudden spontaneity". For example, Einstein, after years of fruitless calculations, suddenly had the solution to the general theory of relativity revealed in a dream: "like a giant die making an indelible impress, a huge map of the universe outlined itself in one clear vision". Hadamard described the creative process, using the stages of von Helmholtz and Poincaré.

Marie-Louise von Franz, a colleague of Carl Jung, confirmed the work of Hadamard by noting that in these scientific discoveries "an always recurring and important factor ... is the simultaneity with which the complete solution is intuitively perceived and which can be checked later by discursive reasoning".

The first formal analysis of the creative process from the point of view of the psychologist can be found in J.P. Guilford's 1950 address to the American Psychological association [20]. Guilford introduced the distinction between convergent and divergent thinking. Other researchers have occasionally used the term 'flexible thinking', which is a combination of the two (convergent and divergent) and is roughly similar to creative thinking.

But others took a more pragmatic approach. Alex Osborne taught the technique of brainstorming. Genrikh Altshüller introduced his Theory of Inventive Problem Solving (TRIZ), and Eduard De Bono [11] had some success with the ideas of lateral thinking, the six thinking hats, etc, from the 1960s onwards.

In 1964, in The act of creation, Arthur Koestler [22] distinguished three types of creative individual: The Artist, the Sage, and the Jester. Koestler also introduced the idea of bisociation, wherein creativity arises as a result of the intersection between two different frames of reference. Thomas Kühn [25], in The structure of scientific revolutions (1970), speaks of the juxtaposition of an old and a new paradigm as a key to scientific revolution.

Abraham Maslow [28] formulated his famous hierarchy of needs in 1968. And creativity is, in this hierarchical scheme, an essential element in self-actualisation. Maslow distinguished between primary creativity (the flash of inspiration that 'sees' a final product before it had been created) and secondary creativity (working out and developing the inspiration - seeing it through).

In 1992 Finke et al. introduced the Geneplore model, in which creativity takes place in two phases. In the 1990s various approaches in cognitive science that dealt with metaphor, analogy, and structure mapping converged on an integrative approach to the study of creativity in science, art, and humour under the term 'conceptual blending'. 
Some theories (for example, Russ and Subramaniam) suggest that creativity may be particularly susceptible to affective influence. Affective disorders, or disorders of the mood, include depression and bipolar illness. The elation (positive affect) following breakthrough creative output is well known. Similarly well known (for example, in Brewer and in the comparative work of Arnold Ludwig at the University of Kentucky) is the significant correlation between affective psychosis and creative achievement. Also, positive affect (good mood) is often a precursor to enhanced creativity.

Ellis Paul Torrance proposed the 'threshold hypothesis' to explain the relationship between creativity and intelligence. There will be a positive correlation between creativity and intelligence only in a sample of highly intelligent people; a threshold of intelligence seems to be necessary for creativity.

After 2000, some authors (such as Flaherty and VanderVert) mapped the creative process on brain anatomy; but these explorations are at an early and as-yet-inconclusive stage.

In Talent is overrated, Geoff Colvin [8] rejects the popular notion that the genius of a Tiger Woods, a Mozart, or a Warren Buffett is inborn and unique to only a few individuals. He cites research that refutes the value of precocious innate ability, and provides numerous examples of the intense hard work that high achievement demands. The world has so few truly great performers, not because there is too little talent, but because so few people have the necessary drive to pay the price.

Daniele Coyle in The talent code [9] describes the importance of deep practice, ignition and master coaching. 'Deep practice' is that deliberate repetitive mastering of leading edge performance through trial and error; 'ignition' occurs during an epiphany-like moment under the influence of a great master; and 'master coaching' describes mentoring. These three unique steps are common to sports people, artists, and technical people alike.

The importance of myelin (white matter) and the formation of myelin-clad 'hard-wired' nerve paths in 'deep practice' to compensate for the inevitable degeneration of neural grey matter helps to explain the remarkable sustained performance of some dedicated scientists, golfers, and musicians late in life.

The above brief overview of an inquiry into creativity reveals a distinct transition, over the past 100 years, from a focus on scientific creativity (Helmholtz, Poincaré, Edison, Einstein, and Hadamard) to more general creativity during the first half of that period; and from a focus on the breakthrough aspect of creativity to the more diffuse and incremental, during the second half. It is only at the end of the second millennium and beyond that the technological community has returned its attention to the knowhow of creativity, by considering it in a more systemic way.

\section{INQUIRY INTO TRANSITIONS IN CREATIVITY}

Over the last 100 years, views about creativity have undergone significant change. It is useful to consider briefly the historical context of creative people during the $20^{\text {th }}$ century. This can be done by looking at some of the main milestones of this period (Table 3).

The 20th century was a period of sweeping geopolitical change, resulting in a fundamental transition from a bipolar to a multi-polar balance of power, and the emerging prominence of global terror.

The Romantic period in art (late 18th to early 19th century) was rooted in the Germanic sturm und drang era, which prized emotion over enlightenment. Some of its heroes were Mozart, Haydn, Verdi, Byron, Munch, Chopin, and Rossini. The Romantic period was probably initiated by Beethoven's Third Symphony (The Eroica). Compared with this creative boom in art, the 20th century was a period of relative calm. 


\begin{tabular}{|c|c|c|}
\hline History & Technology & Art \\
\hline Diamond rush 1870 & Edison 1880 & R \& J uliette (T) 1870 \\
\hline Boer War 1899 & Einstein (s) 1905 & La Boheme 1896 \\
\hline World War I 1914 & Einstein (g) 1915 & Picasso Cubism 1907 \\
\hline World War II 1939 & Alec Reeves (PCM) 1938 & Gershwin (R'Blue) 1927 \\
\hline State of Israel 1948 & Transistor 1947 & Anne Franck 1947 \\
\hline De Gaulle inducted 1960 & Moore's law 1964 & The Beatles 1964 \\
\hline Iran-Iraq War 1980 & Apollo 11 1969 & Oscar Peterson 1965 \\
\hline Falklands War 1982 & Space shuttle 1981 & Salman Rushdie 1988 \\
\hline Berlin Wall falls 1989 & WW-Web 1991 & Les Miserables 1990 \\
\hline Saddam hangs 2006 & WDM \& UMT 2002 & Pavarotti dies 2006 \\
\hline
\end{tabular}

Table 3: Context of the 100-year inquiry shift

But the $20^{\text {th }}$ century saw massive growth in technology, with electromagnetism, relativity, quantum theory, lasers, informatics, and aerospace - not to mention the transition from the industrial age to the information age and the peak of the arms race. Scientists and engineers simply became too pre-occupied with these grave matters to attend to the basics of their own creativity.

\section{A UNIFIED THEORY OF CREATIVITY}

Contemporary writers about (conventional) creativity agree that creativity is the capacity to produce "something novel and valuable" (Brewer [4], Sternberg [41]). That 'something' can be an aircraft, a dance, a new dish, a sculpture, or a theory. This broad understanding of creativity contrasts with the scientific focus of the ground-breaking work of Helmholtz, Bühler, Hadamard, Edison, and Poincaré at the turn of the $19^{\text {th }}$ century.

Perhaps the main reason for the frustration with the growing gap between the demand for technical creativity and the current broad understanding of creativity is to be found in the all-encompassing definition of creativity. Some scholars lament the fact that this single broad idea has to explain the creativity of an Albert Einstein and that of a Vincent van Gogh (Sternberg [41]).

This research considers, defines, and explores the creativity of scientists and engineers in a focused way. In science and engineering, immersion in what feels like overwhelming data is often the prelude to a seminal discovery: the subconscious works away in the background, seeking patterns, and then finally emerges as conscious thought to generate that most precious of personal scientific events, a 'eureka' (Atkins [2]).

In searching for a unified and integrated theory of creativity, it is possible to identify four driving factors of creative productivity:

- Motive. Creativity is not spontaneous; it requires an act of will, persistence, and an intelligent creator. In thermodynamic terms, creativity is an effort to decrease entropy. Without deliberate creative intervention, nature reverts to increasing entropy, to more and more chaos.

- Discordance. Creativity requires new and deviant thinking, the juxtaposition of new concepts with convention. Creativity is always risky; it represents dissatisfaction with the status quo and a consequent inductive leap into uncharted waters.

- Constraints. The products of creativity are original and valuable; but creativity is always curtailed by constraints, whether fashion (convention), lack of understanding, inadequate skill, or a shortage of resources. For creative success, these constraints must be overcome.

- Environment. Creativity can be thwarted by an uncooperative environment. Sometimes, of course, frustration with the environment is the challenge to be creative; at other times the lack of environmental encouragement can be so overwhelming as to inhibit creativity. 
The above four-quadrant unified theoretical model derives its validity and robustness from the superimposition of the well-known and well-trusted Learning Styles Model (LSM) of David Kolb [21]. The Kolb model combines four distinct learning styles, or individual preferences, in a four-stage general learning cycle: Watching (reflective observation) $\rightarrow$ thinking (abstract conceptualisation) $\rightarrow$ doing (active experimentation) $\rightarrow$ feeling (concrete experience).

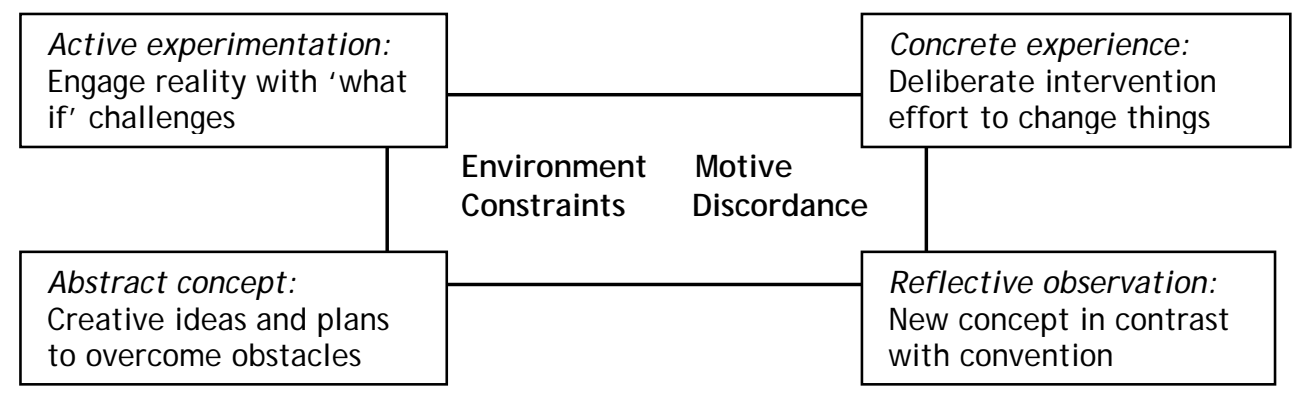

Figure 1: Mapping the unified creativity idea on Kolb's learning styles model

\section{THE CREATIVE WORK OF SCIENTISTS AND ENGINEERS}

The work of scientists and engineers invariably follows the scientific method, which obeys an iterative hypothetico-deductive process, and is based on the philosophical ideas of logical positivism best expressed by the philosophers Immanuel Kant, Ludwig Wittgenstein, and Karl Popper (Mautner [29]).

The scientific method is broadly outlined in the following figure, which is readily understood by starting with 'Problem definition' and then following the straight arrows:

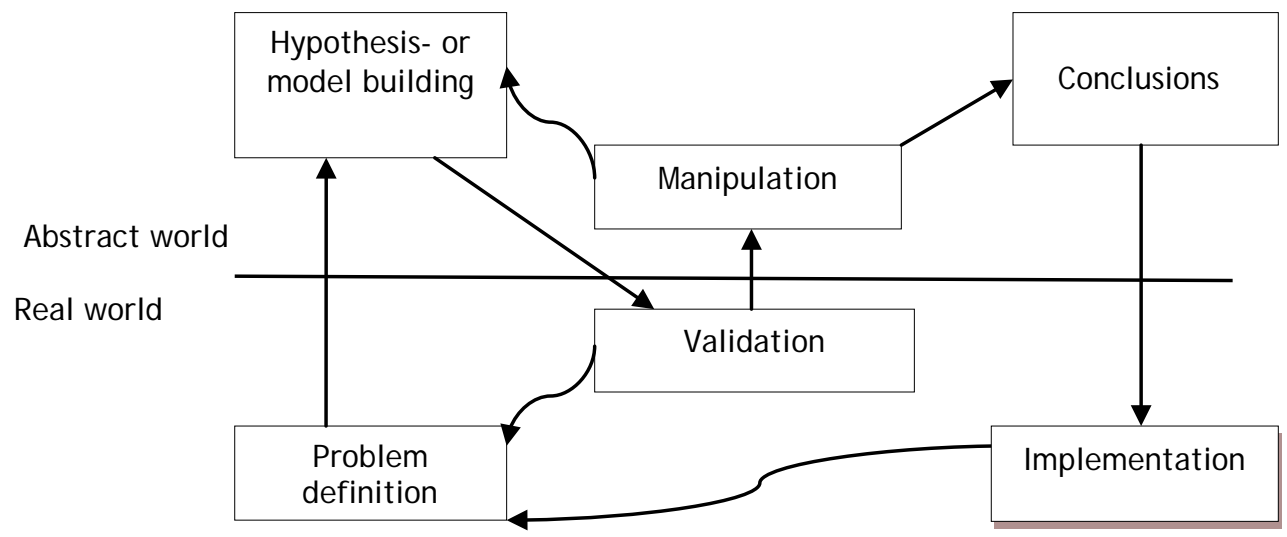

Figure 2: Schematic representation of the scientific method

The curved arrows show some of the iterative review paths. The purpose of this paper is not to offer an in-depth discussion of the scientific method; but for completeness, a number of other important traits of that method should at least be mentioned: 


\begin{tabular}{|c|l|}
\hline 1 & $\begin{array}{l}\text { Scientific knowledge propagates incrementally in concentric waves from the core of existing } \\
\text { knowledge. }\end{array}$ \\
\hline 2 & The scientific method focuses on a formal and quantitative problem statement. \\
\hline 3 & It is empirical and, therefore, focuses on measurement and experimentation. \\
\hline 4 & Peer review, traceability, iteration, and transparency are important. \\
\hline 5 & Statistical hypothesis testing and validation, with real world data, is essential. \\
\hline 6 & $\begin{array}{l}\text { Good science depends on a curious and open mind on the one hand, but also on a healthy } \\
\text { measure of scepticism on the other. }\end{array}$ \\
\hline
\end{tabular}

\section{Table 4: Some important attributes of the scientific method}

More and more, of course, the reach of the senses must be extended with sophisticated measuring instruments such as microscopes, telescopes, $X$-ray and magnetic resonance scanners, remotely-piloted land, air, and maritime vehicles, space probes, and so on. The scientific method culminates in rigorous procedural formats for problem-solving, design, and systems engineering. But the products, processes, services, and businesses that are the usual subjects of science and engineering have life cycles. And it is this life cycle dimension that usually requires the discipline of project or programme management in the practical work of scientists and engineers (Steyn [42]).

In project management, the design method is used repeatedly, in stage after life-cycle stage, as in a spiral, thus progressively creating models and specifications with increasing maturity - that is, with a slow increase in cost and a rapid reduction of risk. In this way a mature design emerges and a cost-effective product enters the market. This procedure raises the question of the difference between design and development. With access to all the constituent technologies, adequate know-how, and all the necessary design data, one can simply retire to one's study and design a product that is ready with bills of quantities for manufacture and operational manuals for use (presuming, obviously, that one has the requisite design talent; if not, it must be developed).

\section{EMPIRICAL TEST}

The creative process in science and engineering has three stages: preparation and incubation, the 'eureka' stage, and elaboration. It is useful to examine the 'eureka' stage with more practical evidence. The circumstances that triggering the 'eureka' moment are often similar for a particular person. In the table below, such 'eureka' events are summarised and two conceptual toggle switches are monitored: one that allows subconscious (or fantasy) thinking to invade the space of reason and logic (Inhibitor on/ off); and one that allows external stimuli (Stimulator on/ off).

\begin{tabular}{|c|c|c|}
\hline Person & Subject & Circumstances \\
\hline Newton \# & Mechanics & I off, S off \\
\hline Faraday \# & Electromagnetism & I off. S on \\
\hline Mendeleyev \# & Periodic table & I of, S off \\
\hline Poincarè \# & Mathematics & I off. S off \\
\hline Einstein \# & Relativity & I off, S off \\
\hline Kekule \# & Benzene & I off, S off \\
\hline Szilard \# & Neutron chain & I off, S on \\
\hline Littlejohn * & Strategy & I off, S on \\
\hline Doep * & Design & I on, S on \\
\hline Finkel * & System & I off, S on \\
\hline Leslie * & Techno plan & I off, S off \\
\hline Tony * & Entrepreneur & I off, S off \\
\hline Johnson * & Programs & I off, S off \\
\hline
\end{tabular}

Table 5: Summary of an empirical 'eureka' test

(\# Historical and * industrial 'eureka' narrative sketches were employed; pseudonyms are used in the latter series. The exceptional case (of Doep*) speaks of the technical 'conscience' in a gifted team.) 


\section{A SYSTEMS APPROACH TO CREATIVITY}

In The web of life, Fritj of Capra [7] introduces the holistic worldview, a new view of the world based on a new perception of reality. He calls it 'deep ecology'.

Capra stresses that the major problems of our time (pollution, climate change, runaway population growth, the digital divide, decreasing biodiversity, global terrorism, etc) cannot be understood in isolation. They are systemic and interconnected. From the systemic point of view, the only viable solutions are those that are sustainable. A sustainable society is one that satisfies its needs without diminishing the prospects of future generations.

The paradigm shift to deep ecology is probably as radical as the Copernican shift. Deep ecology represents a fabric of deep layers of connective webs or interrelationships ('the web of life'), and brings to mind the classic example in chaos theory that the flutter of butterfly wings in China leads to a tornado in Venezuela.

Deep ecology calls for a new kind of creativity and systems engineering, in which the thinking shifts to interconnections, interdependencies, and networks. It invokes the ideas of the self-organising system (autopoiesis), and has resulted in the Gaia (goddess of the earth) concept - the idea of a living earth that self-regulates and maintains its complex ecology with conditions favourable to complex life.

Deep ecology and self-organisation shift the current cognition model based on informatics, from cognition by symbols to cognition by connectivity; from information processing to the emergent (heuristic) properties of adaptive neural networks. The mind thus becomes a highly cooperative interconnected system, and the entire system acquires coherence in intricate patterns. Perception shifts from data processing to instant and ongoing neural pattern recognition [39].

There is a difference between heuristic (unordered) and rule-based (ordered) systems [26]. This sense- and decision-making space can be represented in the so-called Cynefin paradigm.

\begin{tabular}{|c|c|c|}
\hline Cause-effect (C-E) & $\begin{array}{c}\text { Unordered (heuristic) } \\
\text { systems }\end{array}$ & $\begin{array}{c}\text { Ordered (rule-based) } \\
\text { systems }\end{array}$ \\
\hline $\begin{array}{c}\text { Low information } \\
\text { content }\end{array}$ & $\begin{array}{c}\text { Complex systems } \\
\text { systems }\end{array}$ \\
(C-E retroactively understood) & & $\begin{array}{c}\text { Known } \\
\text { (C-E can be discovered) }\end{array}$ \\
\hline $\begin{array}{c}\text { High information } \\
\text { content }\end{array}$ & $\begin{array}{c}\text { Chaotic } \\
\text { systems } \\
\text { (C-E not perceived) }\end{array}$ & $\begin{array}{c}\text { Kystems } \\
\text { (C-E can be perceived) }\end{array}$ \\
\hline
\end{tabular}

The oval in the centre suggests the possibility of transition from one sense-making quadrant to another. Transitions to chaotic systems are often discontinuous.

\section{Table 6: The Cynefin paradigm}

The phrase 'the edge of chaos' was coined by the mathematician Doyne Fanner to describe the discontinuous transition in the behaviour of cellular automata. But this metaphor is now commonly used to describe the behaviour of systems (behavioural, economical, and biological) whose complexity is maximal.

Self-organised criticality (in which complex systems spontaneously organise themselves to operate at a critical point between order and randomness) can emerge from complex interactions in many physical systems including crystal formation, snowflakes, avalanches, forest fires, earthquakes, and heartbeat rhythms. There is recent evidence from the Medical Research Council in Cambridge that the human brain lives "on the edge of chaos" [38]. This 'edge of chaos' meta-stability allows the brain to switch quickly between mental states in responding to the challenges of a rapidly changing environment. 
Mathematicians sift chaos from randomness using a 'phase portrait' - a diagram showing how a complex system evolves in time from its starting point. They look for regions in the phase portrait where the evolutionary paths from many initial states converge. These regions are known as 'attractors'. Chaotic systems have 'fractal attractors' - disjointed shapes that appear similar when viewed on different scales. These complex but repetitive structures create the illusion of randomness. An example is found in water molecules, which freeze rapidly in an unperturbed atmosphere, such as when ice crystals form from water vapour in a frigid undisturbed space; they display a (beautiful) fractal structure.

The deep ecology ideas of Fritj of Capra and other recent theorists such as Murray Gell-Mann [16] will be essential for new understanding in neuroscience and thus of creativity too. In Dawkins [12], Nicholas Humphrey (psychologist and evolutionist) describes the development of a model of consciousness, perhaps one of the most elusive concepts in all of human exploration. He stands, observing and reflecting, at a rail. The first rail is that of the crib of a baby boy. He observes the baby thrashing around with arms flailing, hands grasping randomly, and an occasional grimace showing on his little face. He wonders: What kind of an experience is the boy having?

He then stands at a second rail, observing and reflecting again. This time it is the rail of the gallery in a concert hall. He looks down at the gathering orchestra. As they arrive, the players make themselves comfortable on their chairs, arrange the scores on the music stands, start to tune their instruments, and play a few notes, softly, experimentally. For the moment each musician is in their own world, playing for themselves, oblivious to the cacophony arising from the rest of their colleagues, also tuning and experimenting. Then some sections will try playing a few fleeting bars together.

But they are all waiting for the conductor to appear, to rap his baton on the podium and bring the orchestra to order, to focus on the same opening notes of the same score, to play the same music. Of course the conductor is an important figure in deciding on the repertoire, in setting the style, in arranging, in leading rehearsals, in beginning and timing things. But once the orchestra plays, the conductor's role becomes almost ceremonial, save for an encouragement here and a synchronisation there.

In a way the baby boy is in that stage before the conductor arrives, before the dawning of self-awareness. In much the same way the boy finds himself surrounded by an interconnected web of sections - let's say, the woodwinds, which we shall equate for the moment with the faculty of the senses. There is another section - let's say the strings, which we shall equate for the moment with memory. There is yet another section - let's say percussion, which we shall equate for the moment with logic or with emotion; and so on. There is a whole federation of separate, independently growing mental faculties or subjectivities. In the absence of the conductor, these separate sections each work away at their own tuning, experimenting, and learning - until the conductor comes, until selfawareness arrives, until the ego emerges.

As in the case of the conductor of the orchestra, the initiating and co-operative role of the ego is important; but as the child grows to maturity, the ego starts to take a back seat. It allows other faculties of the federation to take the lead, each in its own time during its own spell of expertise. Perhaps the situation becomes more like that of the famous pianist, Daniel Barenboim, leading the Berlin Philharmonic from behind his piano, with no podium, no baton, just those strong hands, the expressive face, and the overwhelming compulsion of the music. The idea of the co-operative federation remains, but the conductor now simply moves back into the position of the primus inter pares.

The role of the (musical) score is vital; it is the power of the music that binds the orchestra together, more even than the conductor does. The score provides their coherence; it is their love, their commitment, their raison d'etre. This situation reminds one of the learning organisation (Senge [40]), in which vision and values override and empower everyone; the brain of the firm is pushed down through the organisational layers. And so it is with us too: our ambitions, our dreams and visions become central in a web of every 
aspect of our subjectivity. This network integrates every faculty of our federative consciousness, without encroaching on individual sovereignties.

This federative model of awareness, verbalised by one of the most erudite modern exponents of neuroscience and promoted by the world's foremost science writer, is probably as good as it gets, for now. Moreover, Humphrey's idea of awareness and its consequences for creativity fits neatly with the self-organising system ideas of Fritj of Capra and his peers.

The Humphrey hypothesis of awareness provides a powerful holistic metaphor for creativity too. We have been searching everywhere for enhanced creativity: in IQ, in lateral thinking, in brainstorming, in thinking stereotypes, in dreaming, in doodling, in stimulation, and even in madness; but our efforts have tended to specialisation and to exclusive (belief-like) recipes; to pot-luck, as it were.

Humphrey's model of awareness provides a more systemic and heuristic way to understand and enhance creativity, and joins seamlessly with Capra's deep ecology. We enhance creativity for a particular situation when we design an elegant symphonic ensemble of all the sections (or faculties) of consciousness. This adaptive and multidisciplinary design covers envisioning, convergent thinking, divergent thinking, dreaming, memory, the use of coded language, the use of art, perception, values, morality, spirituality, pattern recognition, perception of beauty, all synthesised in an optimal synergistic whole.

As so often happens in exploration, the analytical scalpel that we have applied to human creativity so far has probably cut through tissue, nerve, vein, and sinew alike, thus uncovering stump after bloody truncated stump, and missing, time after time, that beautiful systemic, grander, and more pervasive whole.

\section{INCREMENTAL THEORY EXPANSION}

It now becomes possible to build an incremental expansion of the theory of creativity and 'eureka' by following the systemic approaches of Humphrey and Capra. This expansion builds on existing theory, it is open-ended, and it allows tailoring for science and engineering. Unlike previous approaches to creativity improvement, the expansion concentrates on the importance of erstwhile creative masters, and renders the product somewhat biographical and seemingly anecdotal. The reasoning in the narrative that follows in the pages here below encapsulates the traits of such a theoretical increment.

In science and engineering, the 'eureka' moment is usually embedded in a creative process consisting of three stages (adapted from West [47]): (a) an incubation stage, when the problem is defined and both the quantitative and the qualitative aspects of the problem are thoroughly explored, and focused attention is often deliberately suspended to allow subconscious access to the problem; (b) a 'eureka' stage, when the sudden breakthrough insight usually occurs in circumstances that are unique and particular to the individual concerned; and (c) an elaboration stage, when the output of the 'eureka' event is prepared for implementation. Elaboration usually entails the description of the 'eureka' result in terms accessible to a wider circle of peers, ready for dissemination.

Without a common language and an extensive use of written language, humanity is doomed to mediocrity. It is amazing that humans, late-late comers in the 4.6 billion-year-old evolutionary history of Earth, were so tardy in their early development. But after the discovery of writing some 5,000 years ago, things happened in an accelerating rush (Gelb [17]). A mere 3,000 years after the advent of writing, the Roman Empire was in full swing, the Christian era had started, and some prominent Egyptian, Chinese, Greek, and Roman leaders recorded their philosophies that are still taught and studied today. 
The importance of urbanisation and the development that followed, 2,000 years later, of coded language (writing) led Hans Eysenck, the IQ guru, to state: "Einstein would not have prospered in an igloo, or Mozart in a kraal, or Shakespeare in a wigwam" (Eysenck [15]).

Even so, young Einstein was troubled by his Bavarian high school's discipline (Wenger [46]); he later wrote that the spirit of learning and creative thought were lost in strict rote learning. Einstein was not only a keen violinist but also an avid sailor. As a student in Zurich he often sailed on the lake. A companion of that time, Fraulein Markwalder (his landlady's daughter), noted that every time the wind died down, Einstein's notebook came out and he started writing, almost oblivious to the rest of the crew. But the moment the wind rose again, Einstein was immediately ready to sail, and promptly put away his notebook.

This habit of keeping notes, designs, drawings, formulae, a journal, and other manuscripts is typical of highly creative technical people. They write all the time. This is one of the reasons why we have so much on record from scientists such as Da Vinci, Newton, Poincaré, Darwin, Einstein, and others. They probably did not write in anticipation of fame; they did it because it was an essential part of their trade. That ever-present and stereotypical engineer's affectation, the designer's journal - usually a black hard-covered notebook or electronic equivalent - is much more than a status symbol. One of the best things that students and protégés can learn is to cultivate this habit.

About his joint love for physics and music, Einstein said: "Both are born from the same source and complement each other." His oldest son remembered: "Whenever he felt that he had come to the end of the road or into some difficult situation in his work, he would take refuge in music, and that would, usually, resolve his difficulties." Einstein's sister remarked that playing music seemed to "put him in a peaceful state of mind, which facilitated his reflection". While puzzling over a physics problem, Einstein would play his violin until, suddenly, he would stand up and declare, "There, now I've got it!" A solution had suddenly appeared to him, his sister observed (Wenger [46]).

Writing (using coded speech) and playing the violin (using coded music) clearly had a maj or influence on the creativity of the world's most famous scientist, Albert Einstein. It is noteworthy that Werner Heisenberg, of uncertainty principle fame, was an accomplished pianist. But probably the most famous example of the science-and-art blend is Leonardo da Vinci (1452-1519). Da Vinci was not only the creator of the Mona Lisa and the Last Supper, but was also a musician, a scientist, and a designer par excellence (Mereschkowski [30]).

As you exercise your brain in logical and holistic thinking (science and art), it becomes second nature: you become mentally fit for that way of thinking. The saying about neural hard-wiring is that neurons that fire together, grow together; so simply by thinking hard and often enough about a specific desirable reality, you start to create that reality. And, as success breeds more success, objective reality itself also responds to your projection.

This mechanism or control system was first called 'the power of positive thinking' by the famous pastor, Dr Norman Vincent Peale [34], in 1952. It is often referred to as 'the selffulfilling prophecy'. Numerous do-it-yourself manuals, purporting to contain the secret to success in business and in life, have used it since. They usually do so with undue attention to the 'real secret', namely, the control system. Here a warning is in order: control systems do not work in any old way: they must be designed properly.

Lightweight, bubbling optimists do not convince with their positive but capricious projections. On the other hand, optimistic visionaries with a solid track record get attention every time. Such optimism and enthusiasm are infectious. This is an important environmental feedback and reinforcing mechanism in the power of positive projection. By means of the positive projection of vision, the leader starts to create the reality of that vision. 
But just as "you use it or lose it", so the opposite is unfortunately also true: a lack of thinking - or, worse, negative thinking - about a specific outcome can bring about a negative outcome. So this becomes a self-fulfilling prophecy: it is a virtuous cycle when the reinforcement is constructive, and a vicious cycle when the feedback interferes destructively.

Creating one's own reality by using the power of positive thinking is important for everyone. But for the leader, inventor, innovator, or entrepreneur it is crucial. Good leaders envision a desired outcome with such clarity and such persuasive power that they rally and muster others to share it with enthusiasm. They mobilise and inspire the resources of a talented team, and the snow-balling momentum becomes unstoppable. They create new reality.

They are driven towards their goal by the compulsive rush of their creative energy. In this way, they exploit two powerful forces: (a) the power of the self-fulfilling prophecy, and (b) the addictive pull of the 'eureka' moment. And this irresistible force increases as they get closer to their goal. Their projected vision or subjective reality then becomes objective reality. They are pulled towards their brilliant visionary endpoint almost as if they no longer have any choice in the matter, until they plunge headlong into success, relief, and bliss.

Edison said that genius (innovation, invention, entrepreneurship, or leadership) is $1 \%$ inspiration and $99 \%$ perspiration. This remark is accurate enough, and points to the importance of the preparatory or incubation phase - that phase of the build-up of potential energy before release. Holistically speaking, therefore, the build-up is more important (and certainly much more time-consuming) than the release.

In the theory development of this project, the various modules have been verified either by anchoring them in the literature or in industrial (narrative) experience. In the examples of 'eureka' moments investigated so far, the circumstances of the 'eureka' occurrence were similar. So these circumstances could presumably be replicated. In some cases they occurred under conditions of stimulation, in others without stimulation. It seems to depend on the individual and on the situation.

But the circumstances always occurred at that borderline when the tug-of-war between the conscious and unconscious mind wavered in favour of the subconscious, or when logic and reason were losing the battle with fantasy and fanciful thinking. This condition, in which inhibitions are suspended, allowed the (regular) space of convergent thinking to be invaded by divergent thinking.

In almost every case investigated during this preliminary research, the onset of the 'eureka' moment was sudden, holistic, and brief, and was followed by joy and satisfaction. In every case the 'eureka' moment followed a period of dedicated and persistent hard work or incubation. In most cases there was some intentional suspension of focused attention, just as Poincaré suggested.

Every investigated 'eureka' moment was followed by verification and consolidation. This elaboration stage requires that the brilliant new insight - and perhaps even its outline implementation - be thought out logically and captured in peer language, in common and succinct vocabulary. Einstein, incidentally, was not very competent at the elaboration phase (which today may be called promotion, marketing, and dissemination). Fortunately, peers (such as Hermann Minkowski, Marcel Grossman, Arthur Eddington, and Karl Schwarzchild) recognised the profundity of his work and helped to interpret it for further distribution.

Creative productivity, particularly during the 'eureka' event, is highly dependent on the individual's state of mind. In this respect it is useful to consider the mood of patients with affective disorders such as depression. Their moods can swing from negative to positive; or 
from melancholy to elation. In a really bad (morose and despondent) mood, a patient will sometimes experience a debilitating lack of creativity and productivity. There is no doubt that the high levels of anxiety that are usually associated with intense affective disorder will curtail almost any creative output.

In a good (euphoric) mood the patient will, however, be as sharp, energetic, and enthusiastic as their genetic endowment allows. But moderate human mood cycles are experienced by almost everyone. Some swings are diurnal, others have a monthly period, and some are seasonal (Krech [24]). Clearly, for enhanced creativity, one needs those really positive moments. One of the 'eureka' secrets is, therefore, to find a way to create them.

The importance of physical fitness and exercise for enhanced creativity deserves mention here. About one third of the blood supply in the human body goes to the nurture and temperature control of the brain. Fitness and exercise do not only ensure a regular and good supply of oxygen-rich blood to the brain and to the whole body, of course, but also carry away the stultifying biochemical waste burden. Ask any person with a hangover to confirm their productivity deficit on the morning after. Exercise, moreover, stimulates the endocrine system to release a cocktail of 'feel-good' chemicals into the circulatory system, producing that well-known feeling of 'after action satisfaction'. And it this very state, the state of emotional well-being, which is so conducive to creativity enhancement.

Scientists and engineers employ an optimum blend of convergent and divergent thinking in their quest for creativity (Guilford [20]). The framework in Table 7 is useful in preparing for 'eureka' moments.

\begin{tabular}{|c|c|c|c|}
\hline \multirow{2}{*}{ Creative output } & \multicolumn{2}{c|}{ Logic and reason } \\
\cline { 2 - 4 } Envisioning & Beginner & Beginner & Advanced \\
\cline { 2 - 4 } & Advanced & $\begin{array}{c}\text { The amateur } \\
\text { progrestic but impractical } \\
\text { ideas }\end{array}$ & $\begin{array}{c}\text { Invention, innovation, } \\
\text { entrepreneurship and } \\
\text { leadership }\end{array}$ \\
\hline
\end{tabular}

Table 7: Creativity paradigm (Adapted from Geyer [19])

The above fine balance or mix between logic (serial processing) and vision (parallel processing) is akin to the best blend of science and art (or logic and holism). For optimum creativity, scientists and engineers need the wonder, imagination, and flair of the artist, appropriately combined with the serious reason and perseverance of their own discipline.

Guilford and Geyer were not the only ones to identify these two unique and important thinking styles. Nietzsche introduced the distinction between the 'Apollonians', who favour logic, the analytical approach, and a dispassionate weighing of evidence, on the one hand; and on the other, the 'Dionysians', who lean more toward intuition, synthesis, and passion (Nietzsche [33]). It has now become clear that for optimum creativity, a careful blend of the two thinking styles is essential.

Some critics say that scientists and engineers should develop the finer part of their lives such as art, theatre, history, music and philosophy to make of them more civilised human beings. But the very blend of science and 'the finer things in life' (the best synthesis of Nietzsche's Apollo and Dionysus) is essential for optimum creativity. This supplement is not a 'nice-to-have' cosmetic augmentation, but a vital ingredient in success in science and engineering.

Scientists, engineers, entrepreneurs, and leaders often experience 'eureka'-like breakthrough moments of exceptional insight in their work. Naturally, the explorer, detective, or artist do too. In science and technology, the moments of brilliant new insight are so profound and delightful that scientists over the ages have given them a name: they are called 'eureka moments'. In the Greek language eureka means "I have found it". The exclamation "Eureka!" was reportedly first used by Archimedes some 2,200 years ago when 
he stepped into a bath and noticed the attendant rise in the water level. This phenomenon of fluid displacement and buoyancy became known as the law of Archimedes (Netz [31]). Its contemporary significance lies in the description of a ship's size as so many thousands of tons of displaced seawater.

Successive scientists used the same exclamation during similarly ecstatic moments of discovery. The exclamation "Eureka!" was initially used for 'a-ha!' moments of invention or discovery, but since then, science and technology have progressed dramatically. Today, we know that not only invention, but also innovation, entrepreneurship, and leadership all rely on moments of breakthrough visionary thinking. And these climactic moments of brilliant thought have revolutionary technological and business consequences, much like the revolutionary consequences of the first discoveries. Eureka moments require a discontinuous (or transient) cognitive response, and they deliver peaks of inspired brilliant insight.

The experience of these precious moments is so exquisite and intoxicating that it can lead to addiction. It is as if the energy of all the preceding toil is suddenly bunched up into a single ecstatic spurt of creative productivity. But these moments are even more precious because of what they represent: the triggers of revolutionary progress, the onset of exponential growth in science, technology, and business.

It is important to recognise that some technological breakthroughs can, sadly, also lead to terrible tragedy, as in the consequences of addiction to modern drugs, the dangers of the proliferation of weapons of mass destruction, industrial pollution, the digital divide, and so on. Not every idea-flash will be smart (in a sustainable way); many a moment of 'great insight' will turn out to be a mediocre or even a bad idea. It is not certain that every ideaflash-and-elation will be a significant 'eureka' moment. Even the great J ohannes Kepler laboured under such a 'false start' for many years (Koestler [22]). After all, clever people have many seemingly 'bright' ideas, and healthy people experience many 'feel-good' moments.

So when does the 'eureka'-like experience, complete with subsequent joy, deliver a really good idea? Perhaps a good initial question is this: How hard did you really have to work for your 'eureka' moment? Apart from for a few really fortunate people, there is no such thing as a free lunch. This expression expresses a truth almost as ineluctable as the law of the conservation of energy.

Invention, innovation, leadership, and entrepreneurship sometimes experience the cognitive resonance of that sublime ('eureka') moment of ecstasy. It is a feeling of such exquisite joy, satisfaction, and relief that for some, most other moments of human bliss pale into insignificance. The emotional flush and attendant euphoria of the ecstatic 'eureka' moment is probably caused by the rush of a message mixture from the neuro- and endocrine systems.

Could it be that this rush then sharpens the mind and brings on enhanced mood and faculties for creativity? Is the emotional 'eureka' high also a productive climax creating a gush of seminal creativity? Could it be that the pleasurable sense of reward of these blissful moments of enhanced insight compels you to try again and again? Could it perhaps be that you can become addicted to the flow of your creative juices and signals, as in substance abuse? If so, there is a real danger of addiction to one's creative juices and consequent burnout or weirdness. Many genial people have crossed this line. But it is also probable that enhanced creativity begets more enhanced creativity, thus leading to a streak of creative productivity.

The 'eureka' moment can be compared with the discontinuity of a neural or emotional paroxysm or a cognitive resonance. It is attended by a powerful enhancement of awareness and satisfaction - and, sadly, by its habit-forming power and the consequent danger of addiction. But if one has a tendency towards addiction, one could become addicted to far 
worse substances than 'creative juices'. After all, even weird people like Wolfgang Amadeus Mozart have achieved immortality with it, and so have many other really creative people.

In this respect it may be useful to point out that addictions tend to be monopolistic. With substance addiction, for example, the addict is obsessively and constantly searching for the progressively more elusive 'high', usually to the exclusion of other forms of enjoyment. Emotional addicts (such as the habitual anger junkie or adventure junkie) likewise hunt compulsively and incessantly for their particular 'high' reward moments; and these 'rewards' often crowd out their enj oyment of other pleasures. Balance in life is essential if one wants to enjoy the entire range of human bliss. To experience the full spectrum of life's joys, it is important to indulge sparingly in the luxury of a favourite ecstasy, even if it is 'eureka'.

\section{CONCLUSIONS}

In this research project about creativity and 'eureka':

- It was necessary to narrow down the somewhat general definition of creativity to its specific meaning in science and engineering.

- It was necessary to root this definition in its evolutionary soil to demonstrate its growth and derive its modern meaning.

- It was shown how recent demand for creativity and 'eureka' in science and engineering has risen more rapidly than the understanding of it.

- It became clearer that a more holistic and heuristic approach to creativity enhancement is called for.

- A unified theory of creativity was proposed and tested.

- A number of theoretical expansions were postulated to extend current creativity theory, specifically for science and engineering. These hypotheses are anchored in the literature and supported by industrial evidence. Together they constitute a fresh theoretical layer built on the foundation of existing knowledge.

In the exploration there is no evidence of a 'silver bullet' solution. As always, creativity will demand the kind of total dedication, persistence, and hard work perhaps best described by the expression 'the agony and the ecstasy', about the life of Michelangelo (Stone [43]). But by understanding the creative process and 'eureka' better, scientists and engineers will be able to improve their own creative productivity significantly.

Some creativity improvement methods, such as those of DeBono [11] and Neethling [32], have had some success. But the recent creativity problem - that the demand for creativity from scientists and engineers grows more rapidly than the understanding of it - suggests the need for a significant advance in supporting scientists and engineers on their journey to better creativity. This new theoretical layer, fitting snugly as it does on the core of current creativity theory, can now readily be turned into new practical method. This is, of course, an important next step.

\section{REFERENCES}

[1] Ansoff, H.I. et al. 1976. From strategic planning to strategic management, J ohn Wiley and Sons, UK.

[2] Atkins, P. 2003. Galileo's finger, Oxford University Press, UK.

[3] Bodanis, D. 2000. E=mc : A biography of the world's most famous equation, Walker Books.

[4] Brewer, A. et al. 1993, Develop your creative skills. Mindpower, Dorling Kindersley, Time-Life.

[5] Bryson, B. 2003. A short history of nearly everything, Doubleday.

[6] Bühler, K. 1907. Tatsachen und Probleme zu einer Psychologie der Denkvorgänge. Über Gedanken. Archiv für Psychologie, 9, pp 297-365

[7] Capra, F. 1996. The web of life, Flamingo, London. 
[8] Colvin, G. 2008. Talent is overrated, Nicholas Brealey Publishing.

[9] Coyle, D. 2009. The talent code, Random House, USA.

[10] Darwin, C. 1859. The origin of species and The voyage of the Beagle, Vintage Books. London.

[11] Davidson, J.D. et al. 1999. The sovereign individual, Touchstone Books.

[12] Dawkins, R. 2009. The Oxford book of modern science writing, Oxford University Press.

[13] De Bono, E. 1970. Lateral thinking: Creativity step by step, Harper \& Row / Penguin Books.

[14] Diamond, J. 1997. Guns, germs and steel: The fates of human societies, Norton, New York. USA.

[15] Eysenck, H. 1994. The bell curve, Wall Street J ournal, Dec 1994.

[16] Feldman, A. \& Ford, P. 1979. Scientists and inventors, Aldus Books, UK.

[17] Gelb, I.J . 1963. A chronological study of writing, University of Chicago Press.

[18] Gell-Mann, M. 1994. The quark and the jaguar, Abacus Books, UK.

[19] Geyer, E. 1987. Kreativität im unternehmen, Buchverlag, Landsberg am Lech.

[20] Guilford, J.P. 1950. Convergent and divergent thinking. Speech to the American Psychological Association.

[21] Holm, E. 2000. Inseklopedie van Suider Afrika, Lapa, SA.

[22] Koestler, A. 1959. The sleepwalkers, Hutchinson.

[23] Kolb, D. 1984. Experiential learning: Experience as a source of learning and development, Prentice Hall: Engelwood Cliffs, NJ .

[24] Krech, D. et al. 1974. Elements of psychology, Alfred A Knopf, Inc.

[25] Kühn, T.S. 1970. The structure of scientific revolutions ( $2^{\text {nd }}$ edition), Chicago University Press.

[26] Kurtz, C.F. \& Snowden, D.J . 2003. The new dynamics of strategy: Sense-making in a complex and complicated world, IBM Systems J ournal, 42/ 3.

[27] Lee, R. 2002. The eureka! moment: 100 key scientific discoveries of the $20^{\text {th }}$ century, Routledge.

[28] Maslow, A.H. 1954. Motivation and personality, Harper, New York.

[29] Mautner, T. (ed.) 2000. The Penguin dictionary of philosophy, Penguin Books.

[30] Mereschkowski, D.S. ca 1900. Leonardo da Vinci, Deutsche Buch-Gemeinschaft, Berlin.

[31] Netz, R. \& Noel, W. 2007. The Archimedes codex, Weidenfield \& Nicholson, London.

[32] Neethling, K. 2000. Understanding your whole brain, NBI and Solutionsfinding (Pty) Ltd.

[33] Nietzsche, F. 1985. The birth of tragedy: Out of the spirit of music, Penguin Classics.

[34] Peale, N.V. 1952. The power of positive thinking, Prentice Hall: Englewood Cliffs, NJ .

[35] Poincaré, H. 1902-1908. The foundations of science, New York Science Press.

[36] Rouse, W.B. 1991. Design for success, Wiley series in systems engineering, UK.

[37] Sagan, C. 1998. Billions and billions, Headline Book Publishing.

[38] ScienceDaily. 2009. Public library of science.

[39] Schuermann, J. 1996. Pattern classification: A unified view of statistical and neural approaches, Wiley, NY.

[40] Senge, P. et al. 1999. The fifth discipline, Nicholas Brealey Publishing Ltd, UK.

[41] Sternberg, R.J . 1998. In search of the human mind, Harcourt Brace.

[42] Steyn, J.L. 2006. Design and entrepreneurship, MultiMedia Access, cc.

[43] Stone, I. 1961. The agony and the ecstasy, Doubleday.

[44] Suh, N.P. 1990. Axiomatic design: Advances and applications, Oxford University Press.

[45] Ward, P. 1995. The end of evolution, dinosaurs, mass extinction and biodiversity, Weidenfeld \& Nicholson, UK.

[46] Wenger, W. 1996. The Einstein factor, Three Rivers Press, NY.

[47] West, M.A. et al. 1990. Innovation and creativity at work, J ohn Wiley \& Sons Ltd, UK.

[48] Wood, R. 2000. Managing complexity, The Economist Newspaper, Ltd, London. 